\section{ДОСЛІДЖЕННЯ СТАНУ \\ УПРАВЛІННЯ МІЖНАРОДНИМИ МОРСЬКИМИ ПОРТАМИ}

\section{STUDY OF THE STATE OF MANAGEMENT OF INTERNATIONAL SEAPORTS}

\author{
КАЛІНІНА Г. Г., \\ кандидат економічних наук, \\ доцент, \\ КОБОТОВАГ. В., \\ магістр, \\ IBAHbKIH O. O., \\ магістр, Азовський морський \\ інститут національного \\ університету «Одеська морська \\ академія»
}

\author{
KALININA A., \\ PhD in Economics, Associate \\ Professor, \\ KOBOTOVA G., \\ Master's student, \\ IVANKIN O., \\ Master's student, \\ Azov Maritime Institute National \\ University "Odessa Maritime \\ Academy"
}

У статті підкреслено необхідність впровадження методів та форм управління міжнародних портів задля продуктивності українських портів. Доведено, чому виділені чинники впливають на систему управління порту. Сформовано підгрунтя щодо системи управління на прикладі світових портів.

Ключові слова: система управління міжнародними портами, моделі управління порту, ефективність управління, державні системи управління.

В статье подчеркнута необходимость внедрения методов и форм управления международных портов для производительности украинских портов. Доказано, почему выделенные факторы влияют на систему управления порта. Сформирована почва относительно системы управления на примере мировых портов.

Ключевые слова: система управления международными портами, модели управления порта, эффективность управления, государственные системы управления.

The article emphasizes the need to introduce methods and forms of management of international ports for the productivity of Ukrainian ports. It is proved why the selected factors affect the port management system. The basis for the management system on the example of world ports is formed.

Key words: international ports management system, port management models, management efficiency, state management systems.

Постановка проблеми. В сучасних умовах розвитку ринкової економіки одним з ключових факторів сталого функціонування та постійного розвитку підприємства $€$ наявність чітко сформованої та збалансованої системи управління підприємством. Міжнародні морські порти не $\epsilon$ виключенням. Конкурентоспроможність та розвиток порту напряму залежить від системи управління, яка використовується керівництвом, від того, наскільки ця система збалансована та включає такі фактори, як розробка та впровадження стратегічних та оперативних планів, проведення гарної інвестиційної 
політики, рівень комп'ютеризації та автоматизації робочих процесів, якість наявних трудових ресурсів та системи підвищення рівня їх кваліфікації, здійснення аналізу конкурентного середовища та складання плану ризиків з боку конкурентів та ін. Управління міжнародними морськими портами представляє собою дуже містке та багатогранне поняття, яке $\epsilon$ маловивченим, через що зростає актуальність даної теми дослідження. Окрім цього, міжнародний морський порт $€$ частиною транспортної галузі країни свого місцезнаходження та безпосередньо впливає на розвиток транспортного сектору та економіки загалом.

Метою статті $є$ дослідження систем управління міжнародними морськими портами.

Виклад основного матеріалу дослідження. Морська транспортна система країни забезпечує ефективний засіб переміщення великих обсягів вантажів з найменшим впливом на навколишнє середовище. Наприклад, один 1000-футовий корабель може перевозити таку ж кількість вантажу, як 2800 вантажівок, або сім 100-вагонних складів. Тим не менш, кораблі споживають найменшу кількість палива, що призводить до зниження викидів в атмосферу і меншої кількості аварій. Роль портів має вирішальне значення в судноплавній галузі.

Управління портами відіграє значну роль в управлінні і контролі вартості транспортування, загального часу доставки вантажу від джерела до кінцевого пункту призначення і його мінливості, безпеки вантажу і надійності логістичної компанії, а в кінцевому підсумку і його пропускної здатності. Структура управління морськими портами більшості країн світу в принципі базується на двох концепціях, які можна назвати англійською та французький [1]:

Таблиця 1

Концепції управління міжнародними морськими портами

\begin{tabular}{|c|c|}
\hline Французька & $\begin{array}{l}\text { Розглядає порти як частину єдиної національної } \\
\text { транспортної системи, завдання якої - } \\
\text { задоволення потреб країни в вантажах, що } \\
\text { перевозяться. Економічна діяльність порту в } \\
\text { даному випадку має допоміжний характер. } \\
\text { Передбачається, що дохід повинні приносити } \\
\text { господарюючі суб'єкти, що діють на території } \\
\text { порту, в прилеглому економічному районі. За } \\
\text { рахунок цих доходів покриваються збитки від } \\
\text { експлатації портів. Французка концепція } \\
\text { передбачає лише часткове покриття витрат порту } \\
\text { за рахунок зборів. }\end{array}$ \\
\hline Англійська & 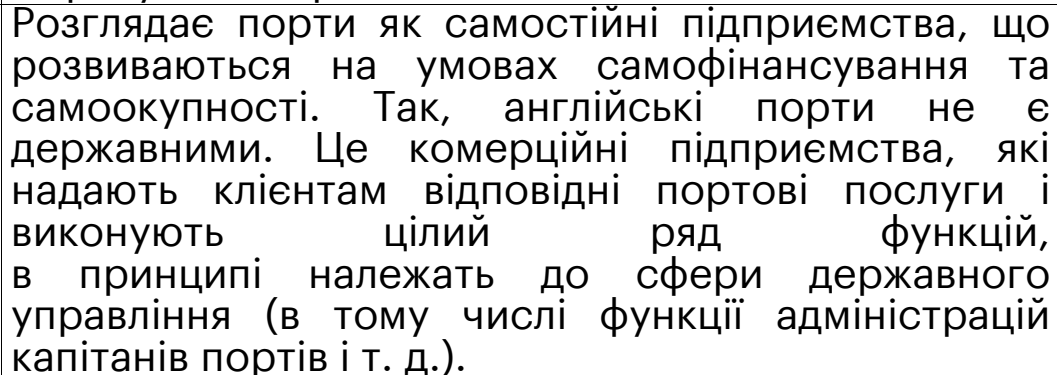 \\
\hline
\end{tabular}

у глобальному контексті роль морських портів як центрів торговельної діяльності сприяє зміцненню розвитку мультимодальної транспортної системи шляхом сприяння збільшенню вантажних мереж. У міжнародних перевезеннях особлива увага приділяється 
таким конкурентним факторам, як інфраструктура портів, якість і спектр послуг, що надаються, здатність портів своєчасно управляти великими обсягами вантажів, вартість і ефективність. Крім того, хаби і перевалочні термінали постійно вдосконалюють свою мережу, щоб виконувати нові ролі в глобальних ланцюжках поставок у зв'язку з величезним зростанням контейнерних вантажів на основних транспортних маршрутах. Добре відомо, що логістична діяльність $€$ сполучною ланкою для ефективного руху вантажів і забезпечення безперебійності операцій і обробки вантажів.

Сьогодні найбільші порти світового класу розглядають можливості міжконтинентальної дистрибуції як найважливіший фактор залучення бізнесу. У зв'язку 3 цим мережева модель матиме безпосередній вплив на вантажопотоки і ланцюжки поставок, i пропоновані оцінки включають в себе облік економічного потенціалу регіону і внутрішніх районів, прогноз зростання портів, перегляд транспортних систем, включаючи інфраструктуру, аналіз взаємопов'язаності модальних зрушень і іншу системну інтеграцію.

Аналіз управління портами включає в себе розуміння умов порту, включаючи внутрішньо портовий розподіл, а також маршрути і внутрішні з'єднання за межами порту. Більш того, наше розуміння глобальної дистрибуції дозволяє нам бачити за межами кордонів порту і вирішувати питання, пов'язані з переміщенням через всю систему дистрибуції. Аналіз тенденцій зростання вантажопотоків, вхідних і вихідних потоків, ефективності транспортної системи, інституційних і нормативних впливів - все це є ключем до виявлення можливостей вдосконалення логістичної діяльності. Іншими важливими факторами, які ми розглядаємо, є транспортні пробки, інтеграція ланцюжків поставок, інформаційні процеси та безпека вантажів. Моделювання бізнес-процесів використовується для аналізу бізнес-операцій та їх оптимізації [2]. Важливою частиною бізнеспроцесів $€$ розробка і використання процесних моделей областей діяльності як основи для реінжинірингу, навчання, комунікації, опису робочих процедур, ініціатив щодо покращення контролю якості, розробки систем і т. д. Моделювання бізнес-процесів допомагає виявити фундаментальні аспекти існуючих процесів, які повинні стати основою для вдосконалення та оптимізації.

Повертаючись до проблеми ефективності управління, в процесі постійно ускладнюється управлінської державної системи, і, як наслідок, аналогічно соціально-економічних відносин, що змінюються, виникла необхідність розмежування проблематики удосконалення та розвитку управління національним виробництвом на окремі аспекти (економічний, правовий, соціальний, кібернетичний та інші) при їх одночасній взаємодії та координованості. Таким чином, базою для вирішення даного завдання $\epsilon$ створення єдиного методичного підходу до об'єкта управління - морського порту, що дозволяє при використанні відповідних економічних методів здійснювати управлінський процес по досягненню конкретних економічних цілей підприємства.

Всі управлінські методи і функції $€$ взаємопов'язаними по відношенню один до одного, створюючи певний цикл, і охоплюють при цьому весь процес управління виробництвом. Слід уточнити, що джерелами формування даного циклу (i початком процесу планування) виступають функції, що знаходяться поза виробничо- 
управлінського процесу (внутрішнього для підприємства), які $\epsilon$ маркетингом. Також управлінські методи, виступаючи в якості інструменту, можуть бути використані для вирішення конкретних завдань [3].

У світовій практиці найбільш поширеними методами управління морського порту $€[5]$ :

Таблиця 2

Найпоширеніші методи управління міжнародними портами

\begin{tabular}{|c|c|}
\hline Метод управління & Опис \\
\hline Централізований & $\begin{array}{l}\text { Порт безпосередньо управляється } \\
\text { Єдиним державним (урядовим) } \\
\text { органом влади }\end{array}$ \\
\hline Регіональний & $\begin{array}{l}\text { Порт перебуває у віданні } \\
\text { регіональних (місцевих) влади, але } \\
\text { контролюється і управляється також } \\
\text { центральним Урядом }\end{array}$ \\
\hline $\begin{array}{c}\text { Управління приватною фірмою } \\
\text { (автономний порт) }\end{array}$ & $\begin{array}{l}\text { Яка орендує засоби та ресурси } \\
\text { (акваторію, причали, під'їзні шляхи, } \\
\text { склади тощо) у державних органів } \\
\text { або місцевої влади }\end{array}$ \\
\hline
\end{tabular}

В нинішніх умовах розвитку ринкового середовища, коли підприємства змагаються за конкурентні переваги, вичерпні ресурси, увагу споживачів, все більше уваги приділяється саме управлінській діяльності. Ії ефективне використання нині відіграє ключову роль.

Так, усі великі порти Нідерландів - це порти-володільці із поєднанням державно-приватного управління (зокрема, Роттердам, Амстердам), стосовно яких держава відповідає за фінансування базової портової інфраструктури загального користування (дамби, хвилеломи, залізничні дороги, інші шляхи сполучення, навігаційне обладнання), портова влада - за фінансування у внутрішню інфраструктуру порту (будівництво доріг в порту, мостів, причалів, причальних стінок та інших об'єктів), приватні портові оператори - за будівництво та модернізацію інфраструктури терміналів (тротуари, підкранові шляхи, будівлі, заводи, крани, залізничні та автомобільні шляхи на території терміналів). Окремо слід зауважити, що Договором про функціонування ЄС передбачено низку положень, які спрямовані на недопущення обмеження чи спотворення конкуренції шляхом надання державної допомоги та засновані на загальному правилі заборони надання прямої державної допомоги, в тому числі морським портам. Виключення складає державна допомога, що сприяє здійсненню важливого проєкту спільного європейського інтересу або усуває істотну шкоду функціонуванню економік державчленів, а також допомога, яка сприяє розвитку певних видів економічної діяльності або певних сфер економіки, якщо така допомога не впливає негативно на умови торгівлі тією мірою, що не суперечить спільному інтересу. Тому існуюча у Нідерландах можливість спільного фінансування державою і приватними портовими операторами будівництва терміналів передбачає компенсацію державі всіх витрат, пов'язаних з таким фінансуванням [4].

У США морські порти перебувають у власності державних корпорацій, які об'єднані у Американську асоціацію портових адміністрацій (ААРА). За даними [6] Адміністрація морських портів за 
узгодженням 3 ААРА самостійно формує свої бюджети і тарифні ставки, хоча Міністерство транспорту США має право вносити до них свої поправки. Фінансування розвитку порту здійснюється переважно за рахунок муніципалітетів і місцеві бюджети штатів (61\% і 37\% відповідно) і лише 2\% фінансування припадає на державний бюджет США [7], що зумовлюється великою кількістю муніципальних портів. Тому найчастіше структура управління портом підпорядковується меру міста, законодавчим органом виступає Асамблея портової влади, а органом самоуправління - Рада порту. Виконавча рада Адміністрація порту і гавані - складається з кількох департаментів, створених за функціональною ознакою.

Значну складнішу систему управління морськими портами має Японія. Це пов'язано з особливостями промислового виробництва країни, в силу яких більша частина морських портів виконують функції промислово-транспортних комплексів, оскільки через острівний стан і гострий дефіцит сировини Японія традиційно розміщувала виробництва важкої і хімічної промисловості на території портів [6]. Морські порти Японії перебувають у веденні місцевої влади (префектури), але контролюються і управляються також і центральним урядом країни, які надають грошові субсидії для розвитку портової інфраструктури. Рішення про розмір субсидій приймається 3 урахуванням категорії порту, яких усього три: 18 особливо важливих портів, які відіграють провідну роль у зовнішній торгівлі країни (порти Токіо, Осака, Иокогама, Кобе та ін.); 110 великих портів, які $\epsilon$ опорними пунктами зовнішньої торгівлі і промислового розвитку країни і окремих регіонів; близько 1000 інших (периферійних) портів. Адміністрація порту підпорядковується губернатору префектури, в Асамблеї порту у рівних пропорціях представлені і префектура, і муніципалітет, до ревізуючої структури входять представники префектури, муніципалітету і Асамблеї порту, президентом порту виступає мер міста, а віцепрезидентом - заступник мера. Бюджет і розвиток портів здійснюються на основі п'ятирічного плану [7].

Проведений аналіз зарубіжного досвіду регулювання розвитку міжнародних морських портів дозволяе узагальнити стратегічні завдання держави:

- забезпечення комплексного розвитку та підвищення конкурентоспроможності портової галузі;

- забезпечення належного утримання, ефективного управління та використання стратегічних об'єктів портової інфраструктури;

- залучення на довгостроковий період приватних інвестицій для розвитку об'єктів портової інфраструктури;

- створення умов для провадження господарської діяльності в морському порту, рівного доступу до послуг, що надаються в морському порту;

- забезпечення безпеки мореплавства, життя і здоров'я людей та господарської діяльності, що провадиться в морському порту, безпечної експлуатації об'єктів портової інфраструктури;

- забезпечення здійснення нагляду (контролю) за безпекою на морському транспорті;

- забезпечення матеріально-технічного і технологічного розвитку портової галузі та підготовки кадрів; 
- недопущення забруднення навколишнього природного середовища, дотримання вимог щодо використання та охорони водних об'єктів у межах території та акваторії морського порту;

- забезпечення екологічної безпеки відповідно до міжнародних стандартів.

Висновок та перспективи подальших досліджень. у цьому дослідженні система управління порту визначається шляхом моделювання вибору порту. Таким чином, проаналізована інформація відносно системи управління на міжнародних морських портах, що представляє собою різні напрямки, методи та підходи щодо покращення системи управління морськими портами, що формувалися протягом багатьох років під впливом різних факторів. Перш за все під впливом зовнішніх факторів, тобто оточуючої середи, економічного устрою, розвитку ринкових відносин. Все це здійснює неабиякий вплив на формування ефективної та дієвої системи управління діяльністю підприємства.

Сучасний стан економіки засвідчує необхідність пошуку нових, інноваційних методів управління на морських портах України (на прикладі міжнародних портах), що будуть повністю адаптовані до сьогоднішнього стану міжнародної економіки.

\section{Література:}

1. Mirotin L. B., Nikolin V. I., Tashbaev I. E. Transport Logistics: textbook for motor transport universities. Omsk, 1994.

2. Monakhov V.M. Methods of optimization. Moscow: Prosveshchenie Publ., 1976.

3. Sergeev V. I. Management in business logistics. Moscow: Filin Publ., 1997.

4. Smekhov A. A. Logistics. Moscow: Znanie Publ., 1990.

5. Bezlutskaya A. P.,. Ben A. P, Kolegaev M. O., et al. Management of marine resources: a textbook. Kherson: grin D. S., 2014. 100 p.

6. Regional Economics and management: textbook. Moscow: infra-m publ., 2006. 416 p.

7. Basovsky L. E. Management: a textbook. Moscow: infra-m publ., 2006. 216 s.

The article emphasizes the need to introduce methods and forms of management of international ports for the performance of Ukrainian ports. It is proved why the selected factors affect the port management system. The basis for the management system is formed on the example of world ports.

In a global context, the role of seaports as trade hubs contributes to strengthening the development of a multimodal transport system by facilitating the expansion of cargo networks. In international transport, special attention is paid to such competitive factors as port infrastructure, quality and range of services, the ability of ports to manage large volumes of cargo in a timely manner, cost and efficiency. In addition, hubs and transshipment terminals are constantly improving their network to fulfill new roles in global supply chains due to the huge growth of containerized cargo on major transport routes. It is well known that logistics activities are the link for efficient movement of goods and ensuring the continuity of operations and cargo handling. 
Today, the largest world-class ports consider the opportunities of intercontinental distribution as the most important factor in attracting business. In this regard, the network model will have a direct impact on cargo flows and supply chains, and the proposed estimates include taking into account the economic potential of the region and the interior, forecasting the growth of ports, reviewing transport systems, including infrastructure, analyzing the interconnectedness of modal shifts, and other system integration.

УДК 656.07

DOI: 10.35340/2308-104X.2021.90-1-11

\section{АНАЛІЗ ІНВЕСТИЦІЙНОЇ ПРИВАБЛИВОСТІ МОРСЬКИХ ПОРТІВ УКРАЇНИ}

\author{
КРАВЧЕНКО А. В., \\ кандидат економічних наук, \\ доцент, \\ KOCЯK A. B., \\ магістр, \\ KOCAPEHKO B. B. \\ магістр, Азовський морський \\ інститут національного \\ університету «Одеська морська \\ академія»
}

\section{ANALYSIS OF INVESTMENT ATTRACTIVENESS OF SEAPORTS OF UKRAINE}

\author{
KRAVCHENKO A., \\ $\mathrm{PhD}$ in Economics, Associate \\ Professor, \\ KOSYAK A., \\ Master's student, \\ KOSARENKO V., \\ Master's student, \\ Azov Maritime Institute National \\ University "Odessa Maritime \\ Academy"
}

У статті підкреслено необхідність впровадження методів та прийомів для визначення необхідності інвестування у портову галузь України. Доведено, чому недостатнє інвестування впливає на портову галузь України. Сформовано підгрунтя щодо інвестицій у портову галузь на прикладі портів України.

Ключові слова: інвестиційна привабливість, морські порти.

В статье подчеркнуто необходимость внедрения методов и приемов для определения необходимости инвестирования в портовую отрасль Украины. Доказано, почему недостаточное инвестирование влияет на портовые отрасль Украины. Сформировать основы касательно инвестиций в портовую отрасль на примере портов Украины. порты.

Ключевые слова: инвестиционная привлекательность, морские

The article emphasizes the need to implement methods and techniques to determine the need for investment in the port industry of Ukraine. It is proved why insufficient investment affects the port industry of Ukraine. The basis for investments in the port industry has been formed on the example of Ukrainian ports.

Key words: investment attractiveness, seaports.

Постановка проблеми. Морська галузь України безпосередньо пов'язана з економікою країни в цілому. Продуктивність морської 